\title{
Work Motivation and Satisfaction and Its Impact on Lecturer Performance
}

\author{
Hanafiah $^{1}$, Nasrun $^{2}$, Restu $^{3}$ \\ ${ }^{1}$ Universitas Samudra, Indonesia \\ ${ }^{2,3}$ Postgraduate Program in Universitas Negeri Medan, Indonesia \\ hanafiah1969.mpd@gmail.com
}

\begin{abstract}
The performance of lecturers in a university is measured through Tri Darma namely education, research, and community service. This research is a quantitative study using regression analysis. The research sample was 186 lecturers at Samudra Langsa University determined using tablesKrejcie. The questionnaire is a data collection tool used in this study. Data analysis using EViews.10 The results showed that partially; (1) work motivation (XI) influences lecturer performance; (2) job satisfaction has an effect onlecturer performance; and simultaneously obtained that; (3) work motivation and job satisfaction have a positive and significant effect on lecturer performance. The magnitude of the contribution of independent variables to the dependent variable is $27.86 \%$ and the rest $72.14 \%$ is influenced by variables not observed in this study. So it can be concluded thatfor one of the efforts that can be done to improve the performance of lecturers at Samudra Langsa University is to increase the motivation and job satisfaction of lecturers.
\end{abstract}

Keywords

motivation; job satisfaction; performance, lecturers, higher education

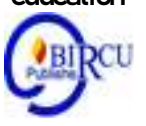

\section{Introduction}

Lecturers have roles, tasks and responsibilities in realizing national education goals (Mulyasana, 2015). Lecturers are one of the important elements in Higher Education that not only carry out education, but also carry out research and coding on society. Lecturers are seen as goodwill (assets) and also an internal factor that plays an important role in the success or failure of an organization in achieving its goals, it is necessary to maintain and manage human resources properly. Maintaning the individual's competence and performanace in language is crucial to take into account, Ramlan (2018). Human resource management in question is the organization must be able to unite the perspectives of employees and leaders of the organization in order to achieve organizational goals, through the formation of a good mental work, provide work motivation, guidance, direction and good coordination in work (Cahayani, 2018).

Lecturers are also the backbone of higher education, especially Samudra Langsa University (Unsam). Highly qualified and dedicated staff is the key to realizing the University's vision, mission and goals. Unsam Langsa has a vision "The realization of an advanced and quality Ocean University in accordance with national education standards in producing quality, professional, competent graduates in their fields, and able to compete in the Global Era". 
So Universities must have superior human resources especially lecturers to be able to realize the vision, mission and goals of the university as well as national education goals. It is expected that all academics are required to be active, creative, innovative and productive in order to: (1) prepare students to become members of the community who have academic and professional abilities in their fields to apply, develop and create science, technology and arts, and (2) develop and disseminate science, technology and art and strive for its use in improving the standard of living of people and enriching national culture.

The government in an effort to advance education in Aceh has changed the status of Unsam to become one of the state universities in Indonesia, in accordance with Presidential Regulation No. 37 of 2013 dated May 13, 2013. This change in status requires Unsam to have highly educated lecturers (strata 3 and minimum strata 2), in an effort to improve the quality of education. Currently Unsam has 450 lecturers consisting of 181 permanent lecturers and 269 non-permanent lecturers. Lecturers with doctoral degrees are 12 people, 4 of them are non-permanent lecturers, lecturers with master degrees are 373 people, and 65 people are attending doctoral program education in various disciplines. Improving the quality of lecturers in order to realize the vision, mission and objectives of the university and improve the performance of lecturers at Samudra Langsa University.

Performance is something that is achieved or performance shown or ability to work, in other words that performance can be interpreted as work performance. If performance is the quantity and quality of work completed by an individual, then performance is the output of the implementation of the taskBakar (2014). So it can be said that performance is related to productivity. The extent to which a person's success in carrying out their work tasks is called the level of performance. People with high performance levels are referred to as productive people, and it is better if people whose level does not reach the standard are said to be unproductive or low performance.

Many factors affect lecturer performance. Among these are remuneration, motivation and job satisfaction (Nasution, Sudiarti, \& Harahap, 2019). The results of his research stated that remuneration, motivation, and job satisfaction together affect the performance of North Sumatra UIN Medan employees. It was added that organizational culture, work stress, motivation had no effect on employee performance. While job satisfaction affects the performance of employees at the Boyolali District Environmental Agency (Hastuti, 2018). Leadership style, motivation, and job satisfaction can also affect employee performance. Three independent variables provide a significant and positive influence on employee performance at PT. Citra Shipyard Batam (Irmaya \& Sirait, 2017).

So it can be interpreted that there are various factors that can affect lecturer performance. Whether it's a factor that comes from within or from outside. An important goal in managing human resources in an organization is the creation of motivation and job satisfaction of the individual concerned so that it will improve performance.

\section{Review of Literatures}

Performance requires the ability of a person to complete his work. (Silalahi, 2013) mention three (3) main factors that influence someone's work. The factors referred to are (1) the ability of individuals to do work; (2) level of effort directed, and (3) organizational support. So that one's performance can be achieved with high quality, then these three factors need to be considered in working. To measure the performance of the relationship of these three factors, it can be written with the formula: 


\section{$P=A \times E x$}

Figure 1. Performance Formula (Silalahi, 2013)

Where:

$\mathrm{P}=$ Performance

A = Ability

$\mathrm{E}=$ Effort

$\mathrm{S}=$ Support

Based on Figure 1 above, the factors that influence employee performance are: (1) ability factors; (2) business factors; and (3) support factors. Therefore, a person's performance needs to be adjusted to their talents, interests and personality. Because, with these three things someone will show their ability to work. However, performance is also influenced by motivation, work ethics, attendance and task design as an effort to obtain work results. Not only that, to get good performance, it is necessary to have equipment and technology support, performance standards, management and colleagues. The components included in each of the formula variables above can be explained through Figure 2 below:

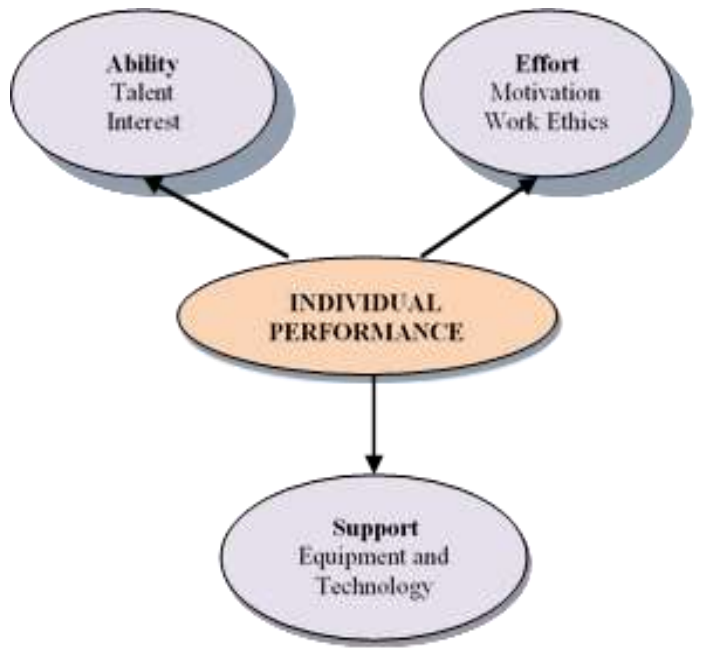

Figure 2. Three Factors that Influence Individual Performance. Source: Adapted from Mathis and Jackson (Setiawan, 2015)

Lecturer performance can be measured by various indicators, but it should not deviate from the rules of Higher Education. As with the results of research that shows that personality and dedication, professional development, teaching skills, relationships and communication, work climate, discipline, welfare, relationships with the community gives positive and significant results on the performance of lecturers by $97 \%$ (Suherman, et al, 2018). To measure the performance of lecturers in tertiary institutions, it must be adjusted to government regulations. Then the assessment of lecturers' work is also regulated by the government. In connection with evaluating the performance of lecturers, that the function of lecturers in their performance description are: (1) lecturers as educators; (2) lecturers as researchers; (3) lecturers as community service; (4) lecturer as a student supervisor; (5) lecturers as leaders; (6) lecturers as innovators; and (7) lecturers as motivators. So that the good or bad performance of lecturers is reflected in the merits of implementing the seven functions. 


\section{Research Method}

Quantitative survey research (Creswell, 2015) by using regression analysis assisted by SPSS 24.0 software was chosen to solve the problems in this study (Sari, 2017). The determination of the research sample was carried out using the help of the Krejcie table(Sugiyono, 2018). For a population of 450 people, by using the Krejcie table, a sample of 186 people was determined according to the work unit (Faculty) in a professional manner.

The questionnaire was used to facilitate the collection of research data(Bungin, 2013). Work motivation is measured through three things namely motives, expectations and incentives(Hasibuan, 2013). Whereas job satisfaction is measured through several aspects namely workload, reward system, organizational and co-worker conduciveness(Patton, 2014). While lecturers' performance is measured based on aspects of education, research, and community service(General, High \& National, 2010).

\section{Result and Discussion}

\subsection{Result}

\section{a. Descriptive Analysis Results}

Data analysis was performed descriptively and inferentially. For descriptive analysis the following results are obtained:

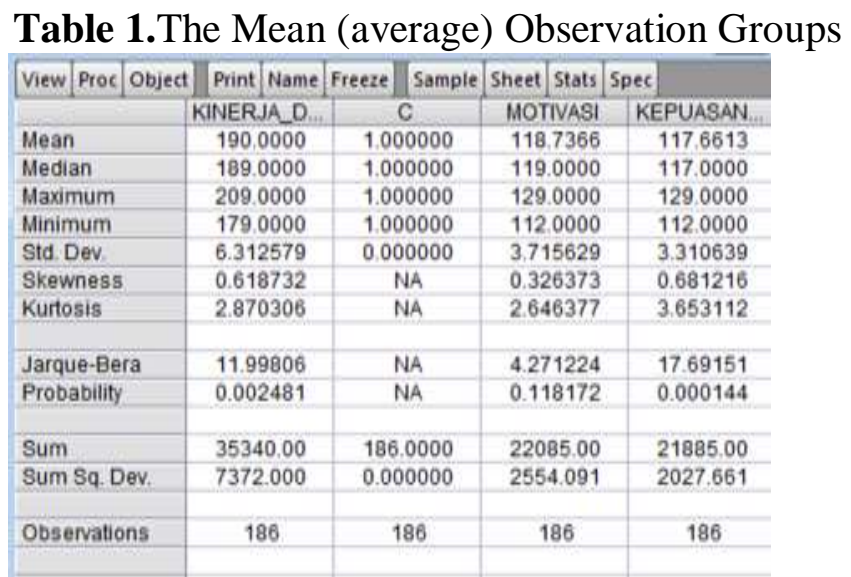

Based on table 1. it is known that the mean (average) observation groups are 190.00 (lecturer performance) 118.73 (motivation), and 117.66 (satisfaction), respectively. The standard deviations are $6.312,3.715,3.310$, and respectively. These results indicate that the data distribution is good.

\section{b. Results Description of Work Motivation (X1) Lecturer}

The results of calculations on research data on work motivation variables (X1) obtained the lowest score of 112 and the highest score of 129, with an average value of 118.74 and a standard deviation of 3,716 and a variation of 13,806. From the acquisition of the average value and standard deviation shows that the distribution of research data tends to be normally distributed. To get a clear picture of the distribution of work motivation variable scores (X1) as well as the number of respondents who answered in a certain range 
of values according to the classification using the Sturrges rule into six (6) classes, the data is presented in table 2 below:

Table 2. Frequency Distribution of Work Motivation

\begin{tabular}{|c|c|c|c|}
\hline No & Interval Class & $\begin{array}{c}\text { Absolute } \\
\text { Frequency }\end{array}$ & $\begin{array}{c}\text { Relative } \\
\text { Frequency }\end{array}$ \\
\hline 1 & $112-114$ & 30 & $16.13 \%$ \\
\hline 2 & $115-117$ & 42 & $22.58 \%$ \\
\hline 3 & $118-120$ & 59 & $31.72 \%$ \\
\hline 4 & $121-123$ & 37 & $19.89 \%$ \\
\hline 5 & $124-126$ & 13 & $6.99 \%$ \\
\hline 6 & $127-129$ & 5 & $2.69 \%$ \\
\hline \multicolumn{3}{|c|}{ Total } \\
\hline
\end{tabular}

Based on table 2 above shows that the distribution of work motivation scores (X1) of 72 people $(38.71 \%)$ is below the average value of the class, the difference is 114 people $(61.29 \%)$ is above the average value of the class. This data illustrates that work motivation variables are generally above the grade average value. Furthermore, to make it easier for readers to understand the work motivation variable, it is also presented through a histogram as shown in Figure 2 below:

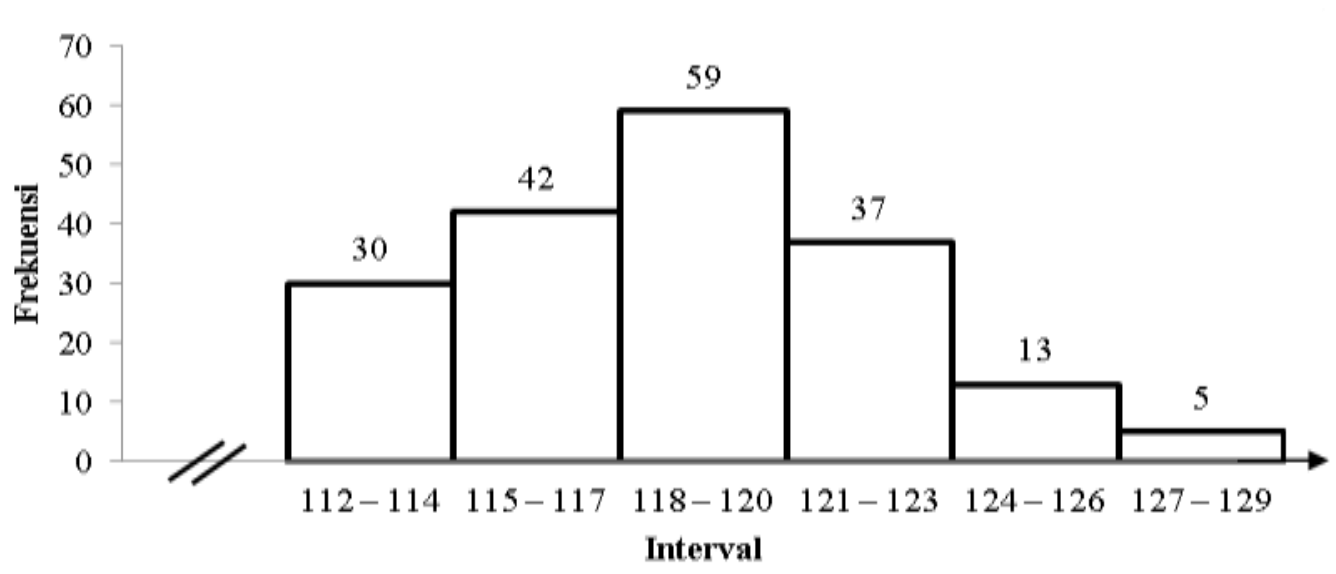

Figure 3. Histogram for Lecturer Work Motivation Data (X1)

Figure 3 above shows that the concentration of work motivation variable data is above the average value of the class, so it can be concluded that the centralization of work motivation variable data leaning to the right means the data distribution is good. Then it can be explained also the acquisition of calculations based on work motivation indicators is presented in table 3 below:

Table 3. Percentage of Work Motivation Indicators

\begin{tabular}{|c|l|c|}
\hline No & Indicator & $\mathbf{\%}$ \\
\hline 1 & Motif & $35 \%$ \\
\hline 2 & Hope & $32 \%$ \\
\hline 3 & Incentive & $33 \%$ \\
\hline & Total & $\mathbf{1 0 0 \%}$ \\
\hline
\end{tabular}


Table 3 above shows the percentage of each indicator of work motivation variables namely motives $(35 \%)$, expectations $(32 \%)$, and incentives $(33 \%)$. This means that the percentage distribution of each work motivation indicator is evenly distributed because it has a balanced percentage.

\section{c. Results Job Description (X2) Lecturer}

The results of calculations on research data on job satisfaction variables (X2) obtained the lowest score of 112 and the highest score of 129, with an average value of 117.66 and a standard deviation of 3,311 and variations of 10,960. From the acquisition of the average value and standard deviation shows that the distribution of research data tends to be normally distributed. To get a clear picture of the distribution of job satisfaction variable scores (X2) as well as the number of respondents who answered in a certain range of values according to the classification using the Sturrges rule, the data is presented in table 4 below:

Table 4. Frequency Distribution of Job Satisfaction

\begin{tabular}{|c|c|c|c|}
\hline No & Interval Class & $\begin{array}{c}\text { Absolute } \\
\text { Frequency }\end{array}$ & $\begin{array}{c}\text { Relative } \\
\text { Frequency }\end{array}$ \\
\hline 1 & $112-113$ & 19 & $10.20 \%$ \\
\hline 2 & $114-115$ & 27 & $14.52 \%$ \\
\hline 3 & $116-117$ & 52 & $27.96 \%$ \\
\hline 4 & $118-111$ & 45 & $24.19 \%$ \\
\hline 5 & $120-121$ & 21 & $11.29 \%$ \\
\hline 6 & $122-123$ & 10 & $5.38 \%$ \\
\hline 7 & $124-125$ & 8 & $4.30 \%$ \\
\hline 8 & $126-127$ & 2 & $1.08 \%$ \\
\hline 9 & $128-129$ & 2 & $1.08 \%$ \\
\hline \multicolumn{4}{|c|}{ Total } \\
\hline
\end{tabular}

Based on table 4 above shows that the distribution of job satisfaction scores (X2) in general the total data distribution that is below the average value is 98 people $(52.69 \%)$. While the distribution of data that is above the overall average value of 88 people (47.31\%). This data illustrates that job satisfaction variables are generally below the grade average value. Furthermore, to facilitate the reader understanding the job satisfaction variable, it is also presented through a histogram as shown in Figure 4 below:

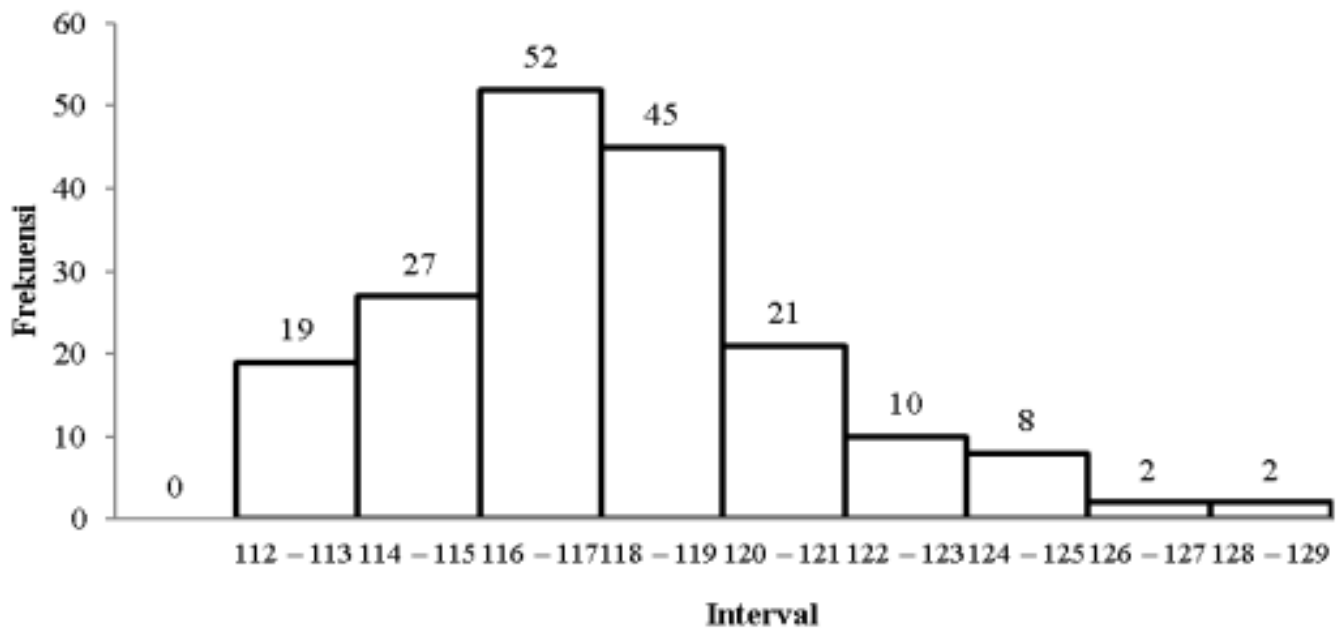

Figure 4. Histogram of Job Satisfaction (X2) 
Figure 4 above shows that the concentration of job satisfaction variable data is below the average value of the class, so it can be concluded that the convergence of job satisfaction variable data tends to the left. Then it can be explained also the acquisition of calculations based on job satisfaction indicators presented in table 5 below:

Table 5. Percentage of Job Satisfaction Indicators

\begin{tabular}{|c|l|c|}
\hline No & \multicolumn{1}{|c|}{ Indicator } & Percentage \\
\hline 1 & Job challenges & $25 \%$ \\
\hline 2 & Reward system & $25 \%$ \\
\hline 3 & Organizational conduciveness & $25 \%$ \\
\hline 4 & Co-workers & $25 \%$ \\
\hline \multicolumn{2}{|c|}{ Total } & $\mathbf{1 0 0 \%}$ \\
\hline
\end{tabular}

From table 5 above, it can be seen that all indicators of job satisfaction have an even distribution because they have a balanced percentage.

\section{d. Results Lecturer Performance Description (Y)}

The results of calculations on research data on lecturer performance variables (Y) obtained the lowest score of 179 and the highest score of 209, with an average value of 190.00 and a standard deviation of 6,313 and a variance of 39,849. From the acquisition of the average value and standard deviation shows that the distribution of research data tends to be normally distributed. To get a clear picture of the distribution of lecturer performance variable scores (Y) as well as the number of respondents who answered in a certain range of values according to the classification using the Sturrges rule, the data is presented in table 6 below:

Table 6. Frequency Distribution of Lecturer Performance

\begin{tabular}{|c|c|c|c|}
\hline No & Interval Class & $\begin{array}{c}\text { Absolute } \\
\text { Frequency }\end{array}$ & $\begin{array}{c}\text { Relative } \\
\text { Frequency }\end{array}$ \\
\hline 1 & $179-182$ & 19 & $10.22 \%$ \\
\hline 2 & $183-186$ & 40 & $21.51 \%$ \\
\hline 3 & $187-190$ & 51 & $27.42 \%$ \\
\hline 4 & $191-194$ & 36 & $19.35 \%$ \\
\hline 5 & $195-198$ & 17 & $9.14 \%$ \\
\hline 6 & $199-202$ & 15 & $8.06 \%$ \\
\hline 7 & $203-206$ & 7 & $3.76 \%$ \\
\hline 8 & $209-212$ & 1 & $0.54 \%$ \\
\hline \multicolumn{4}{|c|}{ Total } \\
\hline
\end{tabular}

Based on table 6 the frequency distribution above shows that the distribution of lecturer performance scores $(\mathrm{Y})$ in general the total data distribution below the average value is 110 people (59.14\%). While the distribution of data is above the overall average value of 76 people $(40.86 \%)$. This data illustrates that lecturer performance variables are generally below the grade average value. Furthermore, to make it easier for readers to understand the lecturers' performance variables, they are also presented through a histogram as shown in Figure 5 below: 


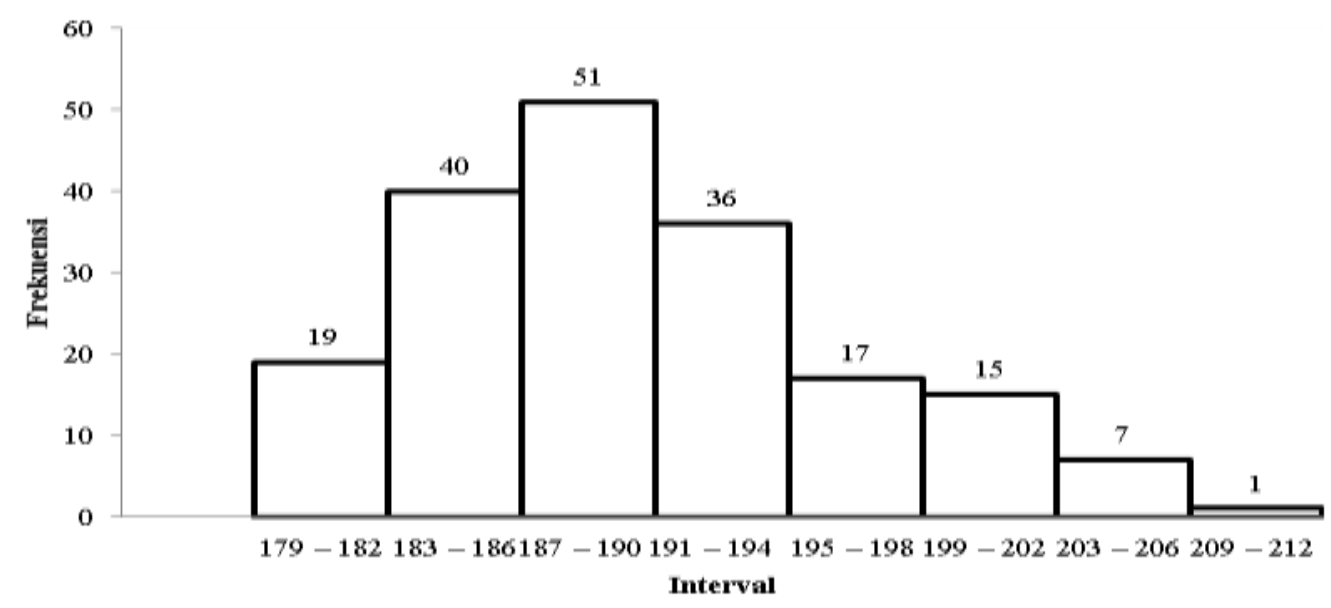

Figure 5. Lecturer Performance Histogram (Y)

Figure 5 above shows that the centralization of lecturer performance variable data is above the average value of the class, so it can be concluded that centralizing the performance variable data tends to the left. Then it can be explained also the acquisition of calculation results based on lecturer performance indicators presented in table 7 below:

Table 7. Percentage of Lecturer Performance Indicators

\begin{tabular}{|l|l|c|}
\hline No & \multicolumn{1}{|c|}{ Indicator } & Percentage \\
\hline 1 & Education and Teaching & $41.67 \%$ \\
\hline 2 & Research and development & $29.17 \%$ \\
\hline 3 & Community service & $29.16 \%$ \\
\hline \multicolumn{2}{|c|}{ Total } & $\mathbf{1 0 0 \%}$ \\
\hline
\end{tabular}

Table 7 above shows the percentage of lecturer performance variables from each lecturer performance indicator was $41.67 \%$ (education and teaching), $29.17 \%$ (research and development), and $29.16 \%$ (community service).

\section{e. Classic Assumption Test Results}

The requirements that must be met in using parametric statistics are: (1) normality test, (2) linearity and significance of regression tests, (3) multicollinearity test; (4) autocorrelation test, and (5) heterokedasticity test. To get the results of a concrete analysis each of these requirements will be calculated in each of the following sections:

(1) Normality test

The results of the analysis using Eviews.10 Software obtained the following results:

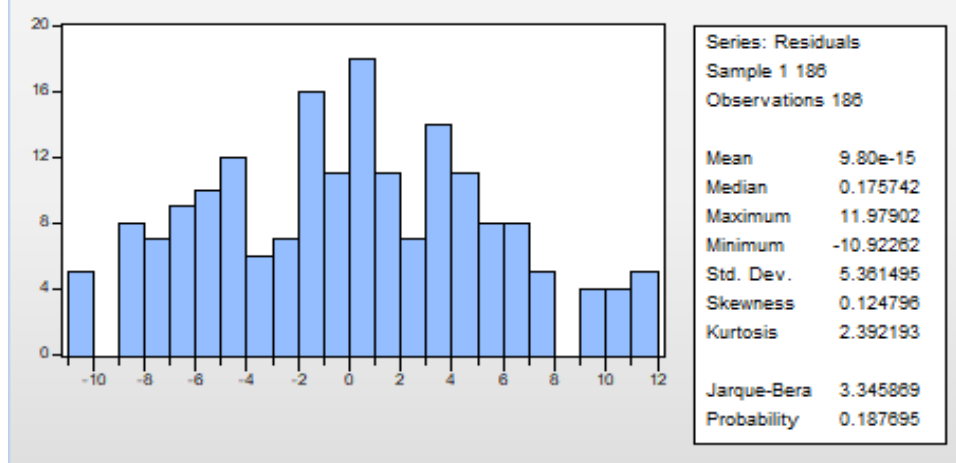

Figure 6. Analysis of Using Eviews 
Jarque-Bera value $=3.345$ with $p$-value $=0.187>0.05$, it can be concluded that the residual model (motivation and job satisfaction) is normally distributed.

(2) Multicollinearity Test

The prerequisite that must be fulfilled in the regression model is the absence of multicollinearity.

Table 8. The Prerequisite of Multicollinearity Test Sample: 1186 Included observations: 186

\begin{tabular}{cccc}
\hline \hline Variable & $\begin{array}{c}\text { Coefficient } \\
\text { Variance }\end{array}$ & $\begin{array}{c}\text { Uncentered } \\
\text { VIF }\end{array}$ & $\begin{array}{c}\text { Centered } \\
\text { VIF }\end{array}$ \\
\hline \hline C & 315.2205 & 2017.599 & NA \\
MOTIVASI & 0.011605 & 1048.224 & 1.019967 \\
KEPUASAN_KERJA & 0.014618 & 1296.321 & 1.019967 \\
\hline \hline
\end{tabular}

Based on the table above, obtained the value of the variance inflation factor (VIF) of the three variables namely motivation and job satisfaction is $1.019<10$ so it can be concluded that between the independent variables there is no multicollinearity problem.

\section{(3) Autocorrelation Test}

The testing method that is often used is the Durbin-Watson test (DW test) with the following conditions:

Table 9. Testing Method of Durbin-Watson

\begin{tabular}{lrlll}
$\begin{array}{l}\text { Sample: } 1186 \\
\text { Included observations: } 186\end{array}$ & & & \\
\hline \hline \multicolumn{1}{c}{ Variable } & Coefficient & Std. Error & t-Statistic & Prob. \\
\hline \hline \multicolumn{1}{c}{ C } & 46.01704 & 17.75445 & 2.591860 & 0.0103 \\
KETIVASI & 0.342787 & 0.107726 & 3.182024 & 0.0017 \\
\hline \hline R-squared & 0.877787 & 0.120904 & 7.260187 & 0.0000 \\
Adjusted R-squared & 0.278630 & Mean dependent var & 190.0000 \\
S.E. of regression & 5.390746 & S.D. dependent var & 6.312579 \\
Sum squared resid & 5317.941 & Akaike info criterion & 6.223230 \\
Log likelihood & -575.7604 & Hannan-Quinn criter. & 6.275258 \\
F-statistic & 35.34196 & Durbin-Watson stat & 1.177314 \\
Prob(F-statistic) & 0.000000 & & & \\
\hline \hline
\end{tabular}

From the calculation results obtained a DW value of 1.177 which is between the values of -2 and +2 , meaning that the path 1 model does not experience autocorrelation problems.

(4) Heterokedasticity Test

Table 10. Heterokedasticity Test

\begin{tabular}{llll}
\hline Heteroskedasticity Test. Breusch-Pagan-Godfrey & \\
\hline \hline F-statistic & 3.841421 & Prob. F(2,183) & 0.0232 \\
Obs*R-squared & 7.494164 & Prob. Chi-Square(2) & 0.0236 \\
Scaled explained SS & 5.049739 & Prob. Chi-Square(2) & 0.0801 \\
\hline \hline
\end{tabular}


From the table above it can be seen that the p-vale (2) value is $0.0236>0.05$, it can be interpreted that this regression model is homokedasticity so it does not experience heterokedasticity problems.

\section{f. Hypothesis Test Results}

Based on partially calculated regression model output data obtained as follows:

\begin{tabular}{|c|c|c|c|c|}
\hline Variable & Coefficient & Std. Error & t-Statistic & Prob. \\
\hline c & 46.01704 & 17.75445 & 2.591860 & 0.0103 \\
\hline MOTIVASI & 0.342787 & 0.107726 & 3.182024 & 0.0017 \\
\hline KEPUASAN_KERJA & 0.877787 & 0.120904 & 7.260187 & $0.000 c$ \\
\hline
\end{tabular}

Table 11. Regression Model Output Data

Tstat value $\mathrm{X} 1=3.182$ and thit value. $\mathrm{X} 2=7.260$ or $\mathrm{p}$-value $=0.0017<0.05$ and $0.000<0.05$, it can be concluded that work motivation (X1) and job satisfaction (X2) have a significant effect on lecturer performance $(Y)$. And simultaneously obtained the value of Fstat $=35,342$ and Fcount $=3,045(35,3423,045)$ or with a sig value. $=0,000<0.05$. Then the decision is to reject $\mathrm{HO}$ and accept $\mathrm{Ha}$. Thus it can be concluded that work motivation (X1) and job satisfaction (X2) simultaneously have a significant effect on lecturer performance $(\mathrm{Y})$.

$\mathrm{R} 2=0.2786$ or $27.86 \%$, this shows that the contribution of $\mathrm{X} 1$ and $\mathrm{X} 2$ to $\mathrm{Y}$ is $27.86 \%$ and the rest $72.14 \%$ is influenced by other variables not observed in this study. To get a regression equation thenlinear regression equation to the regression model test (simultaneously) lecturer performance variables (Y), on work motivation (X1) and job satisfaction (X2) as follows:

$$
\mathrm{Y}=4 \mathbf{4 6 , 0 1 7}+\mathbf{0 , 3 4 3 . X 1}+\mathbf{0 , 8 7 8 . X 2}=47,238
$$

The data gives the meaning that every increase in one score in the work motivation variable is 0.343 and the job satisfaction variable is 0.878 , it will improve the performance of lecturers in the University of Samudra Langsa environment by 47,238 points.

\subsection{Discussion}

Based on the descriptive analysis output obtained the average value of work motivation score (X1) is 118.74 and the average value ideally is 120.5 . After adding up the two scores and dividing by two (2), $98.539 \%$ results were obtained, meaning that the work motivation of lecturers at Samudra Langsa University was included in the very satisfying category. This data is supported by the results of the percentage of each indicator of work motivation variables namely motives $(35 \%)$, expectations $(32 \%)$, and incentives $(33 \%)$. Based on the analysis of the frequency distribution showed that the distribution of work motivation scores (X1) of 72 people $(38.71 \%)$ were below the average value of the class and 114 people $(61.29 \%)$ were above the average value of the class. This data illustrates that the work motivation variable of lecturers at Samudra Langsa University is above the grade average.

Although the results of the analysis conclude that the work motivation of lecturers is above the average value, but this work motivation needs to be maintained, while the ways that can be done to treat work motivation are by: (1) giving rewards or gifts to lecturers 
who excel in working ; (2) making the objectives of the tasks assigned; (3) see or hear the achievements of others; (4) involve yourself in seminars, workshops and so on; and (5) conducting outdoor activities together with his work team, for example outbound.

Motivation must continue to be maintained by lecturers because of course it will impact on performance (Ministry of Finance, nd). The main factors that affect the work motivation of lecturers in this study are (1) fair; (2) wages or salaries; (3) education, (4) skills development; (5) appropriate leadership style; (6) leadership transparency towards subordinates; (7) shows trust; (8) high quality work environment and flexibility.

Based on the results of the output obtained the average value of the count variable work satisfaction (X2) obtained from 186 respondents amounted to 117.66 and an average average of 120.5. Furthermore, it can be made a comparison of the two average values that found $97.664 \%$ job satisfaction at lecturers at the University of Samudra Langsa, including the category of very satisfying. This is reinforced by a balanced percentage among all indicators of job satisfaction, namely: (1) Job full of challenges by $25 \%$; (2) A fair reward system of $25 \%$; (3) Supporting conditions by $25 \%$, and (4) The nature of coworkers by $25 \%$.

This can be explained through the results obtained based on descriptive analysis which showed 43 respondents $(23.11 \%)$ included having a job satisfaction level in the good category and 143 respondents $(76.89 \%)$ had a job satisfaction level included in the quite good category. Thus it can be concluded that the variable job satisfaction at Samudera Langsa University in this study tends to be quite good. In accordance with the results of the propensity test obtained regarding the lecturer job satisfaction variable 67 respondents $(36.02 \%)$ had a good performance level and 119 respondents (63.98\%) had a job satisfaction level included in the quite good category.

Although the concept of job satisfaction is very complex, using the right variables and mechanisms, coupled with the role of a leader (manager) to influence employees so that they feel happy, their presence is noticed and their work environment is better. Then job satisfaction can have a positive effect on employee performance(I. Dugguh \& Dennis, 2014).

Based on the results of the basic statistical test obtained an average score of lecturer performance at Samudra Langsa University is 190 of all respondents, 186 lecturers. While the ideal average score obtained is 194. Comparison of the two scores gives an illustration that the achievement of leadership score at Samudra Langsa University is (190/194) $x$ $100 \%=97.938 \%$. This percentage gives the meaning that the performance of lecturers formed so far has reached the very satisfying category. This result is supported by the results of the analysis of each indicator of lecturer performance variables consisting of three (3) items, namely (1) education and teaching of $41.67 \%$; (2) research and development at $29.17 \%$, and (3) community service at $29.16 \%$.

However, based on the calculation of the frequency distribution, the distribution of lecturer performance scores $(\mathrm{Y})$ is obtained in general, the total data distribution below the average value is 110 people $(59.14 \%)$. While the distribution of data is above the overall average value of 76 people $(40.86 \%)$. This data illustrates that lecturer performance variables are generally below the grade average value. So these results indicate that the performance of lecturers at Samudra Langsa University still needs to be improved.

While the results of the analysis of the tendency of lecturer performance variables. 67 respondents $(36.02 \%)$ had a good performance level and 119 respondents $(63.98 \%)$ had a good performance level. So it can be concluded that the variable performance of lecturers at the University of Samudra Langsa in this study tends to be quite good as evidenced by 
119 respondents $(63.98 \%)$ including having a good level of performance in the category is quite good, but must continue to be improved.

Strategies that can be implemented in order to improve the quality of human resources can be done with (1) a flexible leadership style; (2) promoting teamwork; (3) minimize work formalities; (4) main focus is on internal; (5) developing human resources, and (6) work commitments(Sugiantari, Adnyana Putera, \& Astawa Diputra, 2015). Added Suharsaputra (2013) that the performance of an organization or institution will improve if it meets the indicators including (1) the quality of work; (2) timeliness; (3) initiative; (4) skills or competencies; and (5) good communication.

\section{Conclusion}

The conclusions of the findings and results of the analysis of this research data can be described as follows:

1. The partial hypothesis test results found that motivation AND job satisfaction significantly influence lecturer performance at Samudra Langsa University.

2. Likewise, the results of simultaneous hypothesis testing are known that the two independent variables, namely motivation and job satisfaction, have a significant effect on the performance of lecturers at Samudra Langsa University.

3. The contribution of the independent variable to the dependent variable in this study was $27.86 \%$ and the rest $72.14 \%$ lecturer performance at Samudra Langsa University was influenced by other variables not examined.

4. If the work motivation and job satisfaction of lecturers are increased, it will increase lecturer performance at Samudra Langsa University by 47,238 points.

\section{References}

Bakar, U. A. (2014). Introduction to Human Resource Management in the Perspective of Islamic Education. Surakarta: Fataba Press.

Bungin, B. (2013). Quantitative Research. Jakarta: Kencana Media Predana Group.

Cahayani, E. (2018). The Effect of Motivation, Job Satisfaction and Leadership Style on Lecturers' Performance in the Palembang Private Polytechnic. Business \& Management Bulletin, 05 (01), 30-42.

Creswell, J. (2015). Educational Research; Planning, Implementation and Evaluation of Quantitative and Qualitative Research (Matter I). Yogyakarta: Student Library.

Dugguh, I. S. and Dennis, A. (2014). Job satisfaction theories: Traceability to employee performance in organizations. IOSR Journal of Business and Management, 16 (5), 11-18. https://doi.org/10.9790/487x-16511118

Hasibuan, M. S. (2013). Human Resource Management, Revised Edition. Jakarta. Earth Literacy, 3 (2), 69-81. https://doi.org/10.14710/JSMO.V3I2.4190

Hastuti, T. (2018). The Influence of Organizational Culture, Job Stress, Motivation and Job Satisfaction on Employee Performance (Empirical Study in the Environmental Office of Boyolali District). UMS Repository, 5 (1), 86-96. https://doi.org/10.1016/j.ijmachtools.2009.09.004

Irmaya, A. and Sirait, S. (2017). The Effect of Leadership Style, Motivation and Job Satisfaction on Employee Performance at PT. Citra Shipyard Batam. BENING Journal of Management, 4 (2).

Jenderal, D., Tinggi, P., and National, D. P. (2010). Guidelines for Lecturer Workload and Evaluation of Higher Education Tridharma Jakarta, Indonesia. 
Kusuma, Y. 2019. Motivation Role in Improving Work Effectiveness. Budapest International Research and Critics Institute-Journal (BIRCI-Journal) (2): 281-288.

Ministry of Finance. (nd). Employee Work Motivation. Retrieved April 18, 2019, from https://www.djkn.kemenkeu.go.id/artikel/baca/7754/MOTIVASI-KERJAPEGAWAI.html

Mulyasana, D. (2015). Quality and Competitive Education. Bandung: PT Youth Rosdakarya.

Nasution, H. M., Sudiarti, S., and Harahap, I. (2019). Effect of Remuneration, Motivation and Job Satisfaction on Employee Performance of the North Sumatra State Islamic University Medan. AT-TAWASSUTH, IV (I), 66-88.

Patton, A. (2014). Analysis of the Effect of Leadership and Urban Behavior in Samarinda, 2 (1), 1061-1072.

Ramlan. (2018). Some Steps for Language Maintenance in The Society and Individual. Budapest International Research and Critics Institute-Journal (BIRCI-Journal) Volume I, No 2, June 2018, Page: 62-71 e-ISSN: 2615-3076(Online), p-ISSN: 2615-1715(Print)

Rafida, T., and Julham, T. (2020). Relationship Following Training and Achievement Motivation with Work Satisfaction Learning Citizens in Mandir Institution Courses and Training of Tanjung Balai City. Budapest International Research and Critics Institute-Journal (BIRCI-Journal) (3):598-604

Sari, R. (2017). Introduction to Quantitative Research (1st ed.). Yogyakarta: Deepublish.

Setiawan, B. (2015). The Role of Strategic Human Resource Management Against Company Performance (Case Study of PT. X Service Company in Sidoarjo). Management Student Scientific Review, I (1), 1-13.

Silalahi, U. (2013). Principles of Management ,. Bandung: Refika Aditama.

Sugiantari, S., Adnyana Putera, IGA, \& Astawa Diputra, G. (2015). Spectrum Journal. Journal of Spectrants, 3 (2), 31-40. Retrieved from http://ojs.unud.ac.id/index.php/jsn/article/view/13909

Sugiyono (2018). Quantitative, Qualitative, and R\&D Research Methods. Bandung: Alfabeta.

Suharsaputra, U. (2013). Education administration. Bandung: PT Refika.

Suherman, A., Mulyasana, D., Mulyasa., and Sudrajat, A. (2018). Determinants of Lecturer Performance in Improving the Quality of Academic Services in Higher Education, 1, 1-10.

Werdhiastutie, A., Suhariadi, F., and Partiwi, S. G. (2020). Achievement Motivation as Antecedents of Quality Improvement of Organizational Human Resources. Budapest International Research and Critics Institute-Journal (BIRCI-Journal) (3): 747-752. 